\title{
ANALISIS FAKTOR-FAKTOR PENYEBAB REWORK PADA PEKERJAAN KONSTRUKSI DI KOTA MEDAN
}

\author{
Luthfa Arini, ST, M. Si \\ Politeknik Ganesha Medan \\ luthfarini01@gmail.com
}

\begin{abstract}
Abstrak : Pekerjaan kontruksi yang terjadi di lapangan tidak selalu sesuai dengan rencananya. Penyimpangan sering ditemukan pada pekerjaan finishing, karena dalam pengerjaannya membutuhkan ketelitian dan kerapian. Akibat penyimpangan ini maka pekerjaan harus dilakukan ulang atau rework karena tidak sesuai dengan rencana kualitas mutu perusahaan dan tidak diterima oleh konsumen. Faktor yang dapat menyebabkan rework antara lain faktor desain, manajerial dan sumber daya. Tujuan penelitian ini adalah untuk mengetahui dan menganalisis pengaruh faktor desain, manajerial dan sumber daya terhadap rework dan mengetahui dan menganalisis faktor penyebab rework pada pekerjaan konstruksi. Penelitian ini merupakan penelitian statistik deskriptif dan sifat penelitian merupakan deskriptif asosiatif. Metode pengumpulan data dilakukan melalui penyebaran kuesioner dan studi dokumentasi. Populasi penelitian ini adalah seluruh karyawan PT. Leprim Globalindo Utama, CV. Bintang Multi Graha dan PT. Citra Anugrah Teknika yang berjumlah 67 orang. Metode analisis data yang digunakan adalah metode analisis regresi linear berganda dan uji beda ANOVA dengan menggunakan software spss 22.0. Hasil penelitian menunjukkan bahwa faktor desain, manajerial dan sumber daya secara simultan berpengaruh positif dan signifikan terhadap rework dengan koefisien determinasi $\left(\mathrm{R}^{2}\right)$ 0,675 atau $67,5 \%$. Secara parsial faktor desain yang terdiri dari kesalahan desain, perubahan desain, desain tidak jelas dan pengaplikasian desain di lapangan berpengaruh positif dan tidak signifikan terhadap rework, sedangkan faktor manajerial yang terdiri dari buruknya alur informasi, kurangnya pengawasan, jadwal kerja yang padat dan teamwork yang tidak solid secara parsial berpengaruh positif dan signifikan terhadap rework. Sumber daya yang terdiri dari pertimbangan yang salah di lapangan, kurangnya pengalaman pekerja dan bekerja tidak sesuai prosedur secara parsial berpengaruh positif dan signifikan terhadap rework. Hasil uji beda menunjukkan bahwa tidak terdapat perbedaan pada faktor desain, manajerial dan sumber daya yang menyebabkan terjadinya rework pada pekerjaan kontruksi.
\end{abstract}

Kata Kunci : Desain, Manajerial, Sumber Daya, Rework

\section{Latar Belakang Masalah}

\section{PENDAHULUAN}

Pekerjaan konstruksi khususnya pada pengerjaan gedung mempunyai pekerjaan yang komplit karena banyaknya item pekerjaan yang harus diselesaikan. Pada pekerjaan bangunan terdiri dari dua bagian yaitu pekerjaan fisik dan pekerjaan 
finishing. Namun dilapangan banyak ditemukan penyimpangan pada kualitas mutu bangunan. Penyimpangan yang terjadi di lapangan di mulai dari hal kecil hingga besar. Penyimpangan yang sering ditemukan yaitu dinding bergelombang, pengecatan tidak rapi, dinding tidak siku, kusen yang keropos, atap bocor dan lainnya. Akibat penyimpangan ini maka pekerjaan harus dilakukan ulang karena tidak sesuai dengan rencana kualitas mutu perusahaan dan tidak diterima oleh konsumen. Proses perbaikan kualitas menimbulkan biaya sehingga dapat menurunkan profitabilitas perusahaan atau malah mengakibatkan kerugian perusahaan.

\section{Tujuan dan Manfaat Penelitian}

Adapun tujuan pada penelitian ini adalah:

1. Untuk mengetahui dan menganalisis pengaruh faktor desain terhadap rework yang terjadi pada pekerjaan konstruksi di Kota Medan.

2. Untuk mengetahui dan menganalisis pengaruh faktor manajerial terhadap rework yang terjadi pada pekerjaan konstruksi di Kota Medan.

3. Untuk mengetahui dan menganalisis pengaruh faktor sumber daya terhadap rework yang terjadi pada pekerjaan konstruksi di Kota Medan.

4. Untuk mengetahui dan menganalisis perbedaan faktor penyebab terjadinya rework yang terjadi pada pekerjaan konstruksi di Kota Medan.

Adapun manfaat dari penelitian ini antara lain

a. Bagi Instansi

Manfaat dari penelitian memberikan pengetahuan mengenai faktor-faktor yang paling berpengaruh dalam menciptakan rework ketika perusahaan menangani sebuah proyek sehingga perusahaan dapat mengantisipasi faktor-faktor tersebut.

b. Bagi Peneliti

Menambah dan memperluas wawasan pengetahuan bagi penulis dalam bidang manajemen operasional khususnya yang berkaitan dengan analisis faktor-faktor penyebab rework.

c. Bagi Peneliti Selanjutnya

Hasil penelitian ini diharapkan dapat menjadi bahan masukan bagi semua pihak yang berminat terhadap bidang manajemen operasional, dapat menambah wawasan dan pengetahuan serta sebagai bahan referensi bagi peneliti selanjutnya dalam bidang manajemen operasional.

\section{TINJAUAN PUSTAKA}

\section{Proyek Konstruksi}

Proyek konstruksi merupakan suatu rangkaian kegiatan yang saling berkaitan untuk mencapai tujuan tertentu (bangunan/konstruksi) dalam batasan waktu, biaya dan mutu tertentu. Proyek konstruksi selalu memerlukan resources (sumber daya) yaitu man (manusia), material (bahan bangunan), machine (peralatan), method (metode pelaksanaan), money (uang), information (informasi), dan time (waktu). Dalam 
Suatu proyek konstruksi terdapat tiga hal penting yang harus diperhatikan yaitu waktu, biaya dan mutu (Kerzner, 2006).

\section{Definisi dan batasan rework}

Menurut Love et al (2002) rework adalah melakukan pekerjaan di lapangan lebih dari sekali ataupun aktivitas yang memindahkan pekerjaan yang dilakukan sebelumnya sebagai bagian dari proyek.

Batasan atau hal-hal yang tidak termasuk rework (Andi, 2009:98) adalah sebagai berikut:

1 Perubahan scope pekerjaan mula-mula yang tidak berpengaruh pada pekerjaan yang sudah dilakukan.

2 Perubahan desain atau kesalahan yang tidak mempengaruhi pekerjaan di lapangan.

3 Kesalahan fabrikasi off-site yang dibetulkan off-site.

4 Kesalahan off-site modular fabrication yang dibetulkan off-site.

5 Kesalahan fabrikasi on-site tapi tidak mempengaruhi aktivitas di lapangan secara langsung (diperbaiki tanpa mengganggu jalannya aktivitas konstruksi).

\section{Faktor-faktor penyebab rework}

Faktor penyebab rework dapat dilihat pada Gambar 2.1 berikut ini

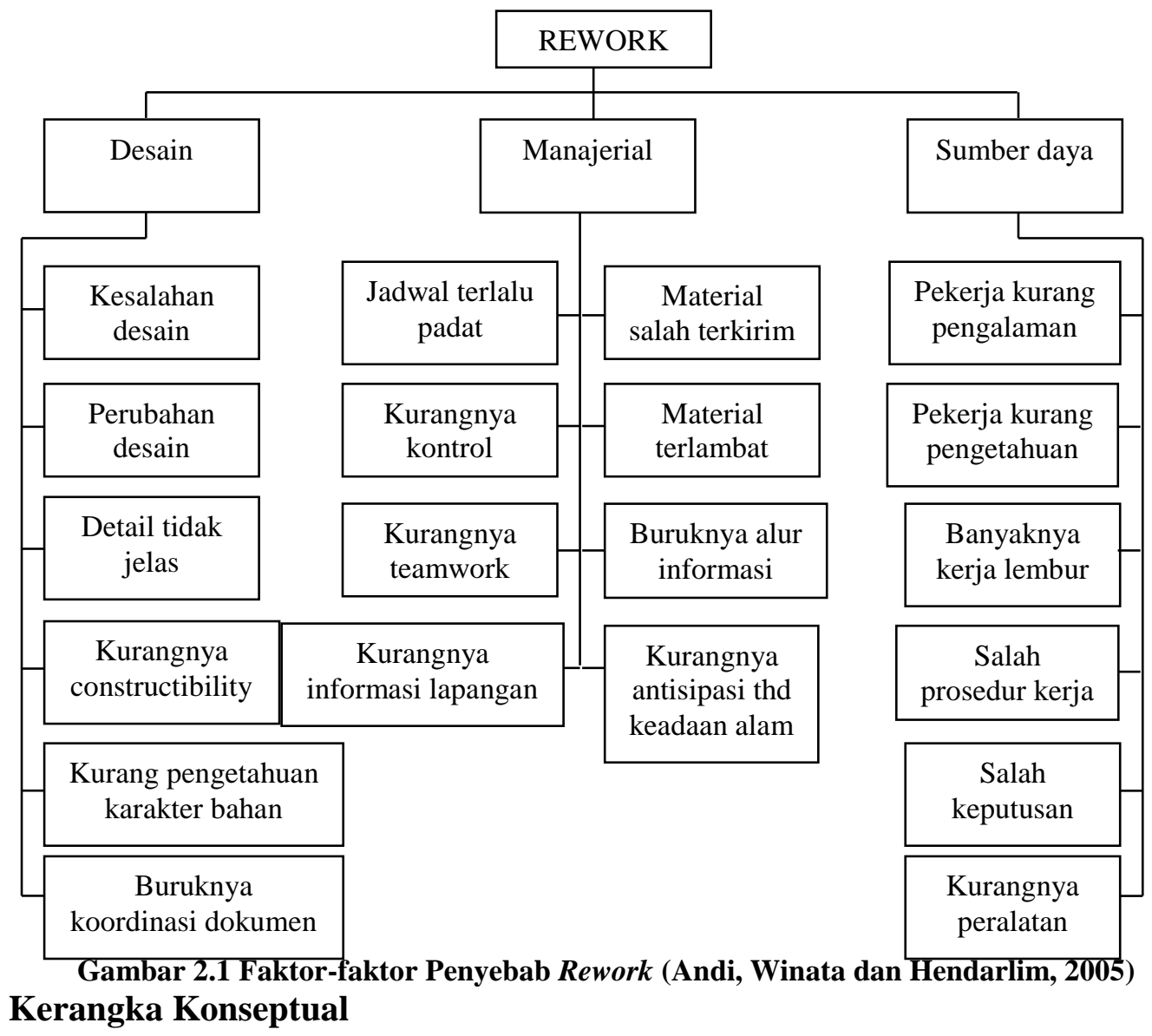




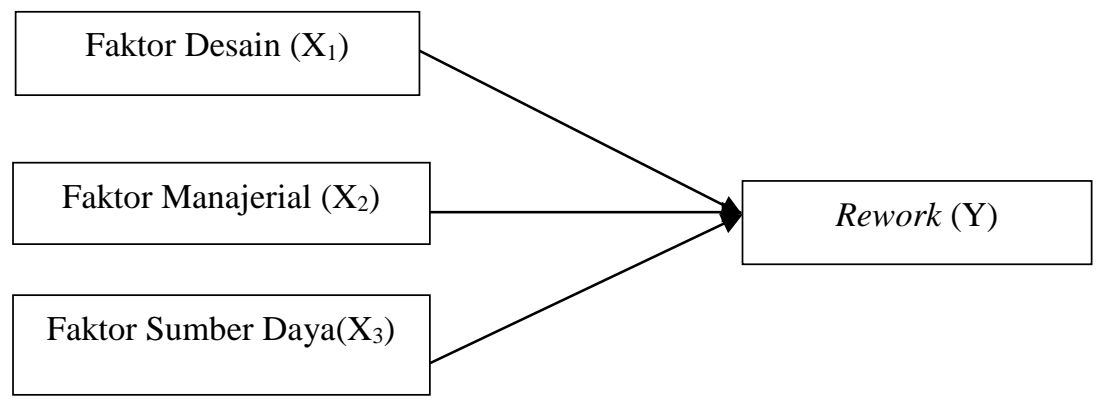

\section{Hipotesi Penelitian}

$\mathrm{H} 1$ :Faktor desain berpengaruh positif dan signifikan terhadap rework yang terjadi pada pekerjaan konstruksi di Kota Medan.

$\mathrm{H} 2$ :Faktor Manajerial berpengaruh positif dan signifikan terhadap rework yang terjadi pada pekerjaan konstruksi di Kota Medan.

H3: Faktor Sumber Daya berpengaruh positif dan signifikan terhadap rework yang terjadi pada pekerjaan konstruksi di Kota Medan.

H4: Terdapat perbedaan Faktor penyebab rework pada pekerjaan konstruksi di Kota Medan.

\section{Jenis Penelitian}

\section{METODE PENELITIAN}

Penelitian ini menggunakan jenis penelitian asosiatif dimana penelitian asosiatif merupakan penelitian yang bertujuan untuk mengetahui hubungan atau pengaruh antar dua variabel atau lebih. Dalam penelitian ini meneliti analisis faktorfaktor penyebab rework pada pekerjaan konstruksi di Kota Medan.

\section{Populasi dan Sampel Penelitian}

Populasi dalam penelitian ini adalah karyawan padaPT. LePrim GlobalindoUtama yang berjumlah 22 responden, CV. Bintang Multi Garaha yang berjumlah 26 responden dan PT. Citra Anugrah Teknika yang berjumlah 19 responden. Total jumlah responden pada penelitian ini yaitu 67 responden. Dalam penelitian ini metode pengambilan sampel menggunakan sensus yaitu semua populasi dijadikan sampel.

\section{Metode Pengumpulan Data}

Pengumpulan data yang dilakukan dengan cara sebagai berikut :

1. Daftar pertanyaan (questionaire) atau pernyataan (statement) yang diberikan kepada karyawan PT. Leprim Globalindo Utama, CV. Bintang Multi Graha dan PT. Citra Anugrah Teknikayang menjadi responden. 
2. Studi dokumentasi, yaitu dengan cara mengumpulkan dokumen-dokumen yang mendukung penelitian ini, struktur organisasi, laporan quality controldan gambaran umum perusahaan.

\section{Uji Validitas dan Reliabilitas}

Uji validitas digunakan untuk mengetahui mengukur sah atau valid tidaknya suatu kuesioner. Suatu Kuesioner dikatakan valid jika pertanyaan pada kuesioner mampu untuk mengungkapkan sesuatu yang akan diukur oleh kuesioner tersebut (Ghozali, 2011: 52). Uji validitas ini dapat dilakukan dengan menggunakan korelasi antar skorbutir pertanyaan dengan total skor konstruk atau variabel. Setelah itu tentukan hipotesis $\mathrm{H}_{0}$ : skor butir pertanyaan tidak berkorelasi positif dengan total skorkonstruk dan Ha: skor butir pertanyaan tidak berkorelasi positif dengan total skorkonstruk

Menurut Situmorang, dkk (2014: 92) menyatakan tekhnik yang digunakan untuk mengukur realibilitas adalah Cronbach Alphadengan cara membandingkan nilai Cronbach Alphadengan standarnya, dengan ketentuan jika :

1. Cronbach Alpha> 0,8 maka instrumen pengamatan dinyatakan realibilitas sangat baik.

2. $0,7<$ Cronbach Alpha $>0,8$ maka realibilitas baik.

3. Cronbach Alpha $<0,7$ maka realibilitas kurang menyakinkan.

\section{Metode Analisis}

\section{Analisis Regresi Linear Berganda}

Metode penelitian ini adalah penelitian analisis sebab akibat, dimana ada variabel independen (sebab) yaituvariabel yang mempengaruhi dan variabel dependen(akibat) yaitu variabel yang dipengaruhi. Persamaan regresi linier berganda dari penelitian ini adalah :

$Y=a+b_{1} X_{1}+b_{2} X_{2}+b_{3} X_{3}+\mathrm{e}$

Di mana :

$\mathrm{a}=$ konstanta

$\mathrm{Y}=$ Rework

$\mathrm{X}_{1}=$ Faktor desain

$\mathrm{X}_{2}=$ Faktor Manajerial

$\mathrm{X}_{3}=$ Faktor sumber daya

$b_{1} b_{2} b_{3}=$ Koefisien regresi masing-masing variabel independen

$\mathrm{e}=$ eror

\section{Analisis beda ( One Way Anova)}

Metode yang digunakan adalah analisis diskriptif digunakan untuk mengetahui adanya perbedaan faktor -faktor penyebab rework pada PT. Leprim Globalindo Utama, CV. Bintang Multi Graha dan PT. Citra Anugrah Teknika. 


\section{Uji Normalitas}

\section{HASIL PENELITIAN DAN PEMBAHASAN}

Uji normalitas bertujuan untuk mengetahui apakah residual yang diteliti berdistribusi normal atau tidak. Distribusi data tidak normal, karena terdapat nilai ekstrem data yang diambil.

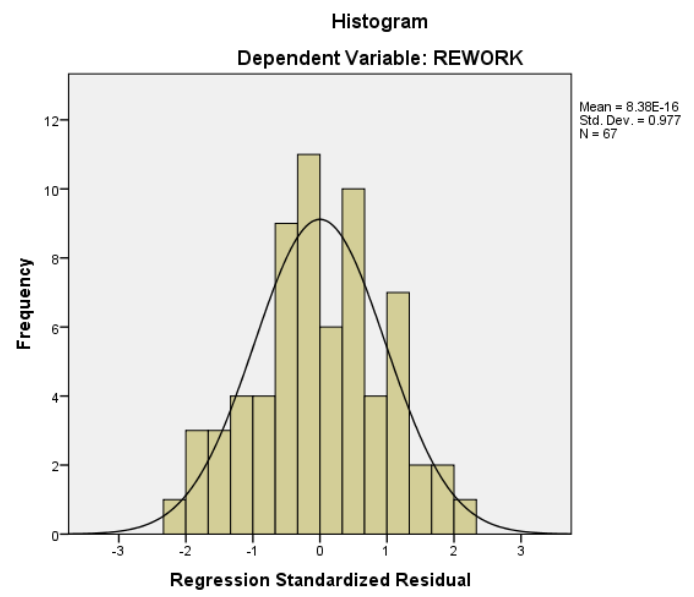

Pada gambar di atas terlihat bahwa variabel berdistribusi normal. Hal ini ditunjukkan oleh distribusi data tersebut tidak miring ke kiri atau ke kanan dan membentuk pola lonceng

\section{Uji Multikolinieritas}

Uji ini bertujuan untuk menguji apakah didalam model regresi linier ditemukan adanya korelasi yang tinggi diantara variabel bebas. Ada atau tidaknya multikolinieritas antar variabel dapat dilihat dari nilai variance inflationfactor (VIF) untuk masing-masing variabel independent terhadap variabel dependent. Pengambilan Keputusannya:

VIF > 5 maka diduga mempunyai persoalan multikolinieritas

VIF $<5$ maka tidak terdapat multikolinieritas

Tolerence $<0,1$ maka diduga mempunyai persoalan multikolinieritas

Tolerence $>0,1$ maka tidak terdapat multikolinieritas

Tabel 4.1

Uji Multikoliniearitas

\begin{tabular}{|c|c|c|c|c|c|c|}
\hline & & \multicolumn{5}{|c|}{ Coefficients $^{\mathrm{a}}$} \\
\hline & \multirow[b]{2}{*}{ Model } & \multicolumn{2}{|c|}{ Unstandardized Coefficients } & $\begin{array}{l}\text { Standardized } \\
\text { Coefficients }\end{array}$ & \multicolumn{2}{|c|}{ Collinearity Statistics } \\
\hline & & $\mathrm{B}$ & Std. Error & Beta & Tolerance & VIF \\
\hline \multirow[t]{4}{*}{1} & (Constant) & -1.390 & 2.009 & & & \\
\hline & DESAIN & .051 & .061 & .085 & .830 & 1.204 \\
\hline & MANAJERIAL & .130 & .062 & .252 & .605 & 1.653 \\
\hline & SUMBER_DAYA & .334 & .079 & .472 & .700 & 1.429 \\
\hline
\end{tabular}

a. Dependent Variable: REWORK

Sumber : Hasil Pengolahan Data Melalui Program SPSS 22.0 (2017) 
Pada Tabel 4.1 variabel Desain, Manajerial, Sumber Daya memiliki nilai Tolerance $(0,830)$; $(0,605)$; $(0,700)$; >0,1 dan nilai VIF(1,204); $(1,653) ;(1,429)$; $<10$ maka variabel tersebut tidak mempunyai persoalan multikolinearitas.

\section{Uji Heteroskedastisitas}

\section{Tabel 4.2}

\section{Uji Glejser}

Coefficients $^{\text {a }}$

\begin{tabular}{|c|c|c|c|c|c|c|}
\hline \multirow{2}{*}{\multicolumn{2}{|c|}{ Model }} & \multicolumn{2}{|c|}{ Unstandardized Coefficients } & \multirow{2}{*}{$\begin{array}{c}\text { Standardized } \\
\text { Coefficients } \\
\text { Beta }\end{array}$} & \multirow[b]{2}{*}{$\mathrm{T}$} & \multirow[b]{2}{*}{ Sig. } \\
\hline & & B & Std. Error & & & \\
\hline \multirow[t]{4}{*}{1} & (Constant) & -.266 & 1.158 & & -.229 & .819 \\
\hline & DESAIN & -.026 & .035 & -.099 & -.729 & .469 \\
\hline & MANAJERIAL & .040 & .036 & .179 & 1.127 & .264 \\
\hline & SUMBER_DAYA & .012 & .045 & .038 & .256 & .798 \\
\hline
\end{tabular}

a. Dependent Variable: res2

Uji ini bertujuan untuk menguji apakah didalam model regresi terjadi ketidaksamaan variance dari suatu residual pengamatan ke pengamatan lain. Jika nilai signifikansi antara variabel independen dengan residual lebih dari 0,05 maka tidak terjadi heterokedastisitas.

\section{Analisis Regresi Linier Berganda}

Tabel 4.3

Hasil uji regresi linear berganda

\begin{tabular}{|c|c|c|c|c|c|c|}
\hline & & \multicolumn{5}{|c|}{ Coefficients $^{\mathbf{a}}$} \\
\hline \multirow[b]{2}{*}{ Model } & & \multicolumn{2}{|c|}{ Unstandardized Coefficients } & $\begin{array}{c}\text { Standardized } \\
\text { Coefficients }\end{array}$ & \multirow[b]{2}{*}{$\mathrm{t}$} & \multirow[b]{2}{*}{ Sig. } \\
\hline & & $\mathrm{B}$ & Std. Error & Beta & & \\
\hline 1 & (Constant) & -1.390 & 2.009 & & -.692 & .492 \\
\hline & DESAIN & .051 & .061 & .085 & .837 & .406 \\
\hline & MANAJERIAL & .130 & .062 & .252 & 2.108 & .039 \\
\hline & SUMBER_DAYA & .334 & .079 & .472 & 4.247 & .000 \\
\hline
\end{tabular}

a. Dependent Variable: REWORK

Sumber : Hasil Pengolahan Data Melalui Program SPSS 22.0 (2017)

Pada Tabel 4.3 dapat dilihat bahwa :

1. Konstanta (a) $=-1,390$ artinya rework yang terjadi di PT. Leprim Globalindo Utama, CV. Bintang Multi Graha dan PT. Citra Anugrah Teknika mengalami penurunan sebesar 1,390.

2. Koefisien regresi Desain yang berupa kesalahan desain, perubahan desain, detail desain yang tidak jelas, kurangnya constructability dan buruknya dokumentasi $\left(\mathrm{X}_{1}\right)=0,051$ artinya akan menaikkan rework pada PT. Leprim Globalindo Utama, CV. Bintang Multi Graha dan PT. Citra Anugrah Teknika sebesar 0,051. 
3. Koefisien regresi Manajerial yang terdiri dari alur informasi yang kurang baik, kurangnya pengawasan yang dilakukan di lapangan, jadwal kerja tidak teratur, dan teamwork yang tidak solid $\left(\mathrm{X}_{2}\right)=0,130$ artinya akan menaikkan rework pada PT. Leprim Globalindo Utama, CV. Bintang Multi Graha dan PT. Citra Anugrah Teknika sebesar 0,130.

4. Koefisien regresi Sumber Daya yang berupa pertimbangan yang salah dilapangan, kurangnya pengalaman kerja, bekerja tidak sesuai prosedur dan kurangnya pengetahuan pekerja $\left(\mathrm{X}_{3}\right)=0,334$ artinya akan menaikkan rework pada PT. Leprim Globalindo Utama, CV. Bintang Multi Graha dan PT. Citra Anugrah Teknika sebesar 0,334.

Uji F (Uji Simultan)

Tabel 4.4

Hasil uji F (Uji Simultan)

\begin{tabular}{|ll|r|r|r|r|r|}
\hline \multicolumn{1}{|l|}{ Model } & & Sum of Squares & Df & Mean Square & F & Sig. \\
\hline 1 & Regression & 65.005 & 3 & 21.668 & 17.614 & $.000^{\mathrm{b}}$ \\
& Residual & 77.503 & 63 & 1.230 & & \\
& Total & 142.507 & 66 & & & \\
\hline
\end{tabular}

Sumber : Hasil Pengolahan Data Melalui Program SPSS 22.0 (2017)

Pada Tabel 4.4 dapat dilihat nilai Fhitung adalah 17,614 dimana Fhitung > Ftabel, yaitu 17,614 > 2,75 dan tingkat signifikansinya $(0,000)$. Oleh karena pada kedua perhitungan yaitu Fhitung > Ftabel dan tingkat signifikansinya $(0,000)<$ 0,05 menunjukan bahwa secara simultan indikator kesalahan pada desain, manajerial dan sumber daya berpengaruh secara signifikan terhadap rework pada perusahaan konstruksi di kota Medan.

Uji t (Uji Parsial)

Tabel 4.5

Uji parsial

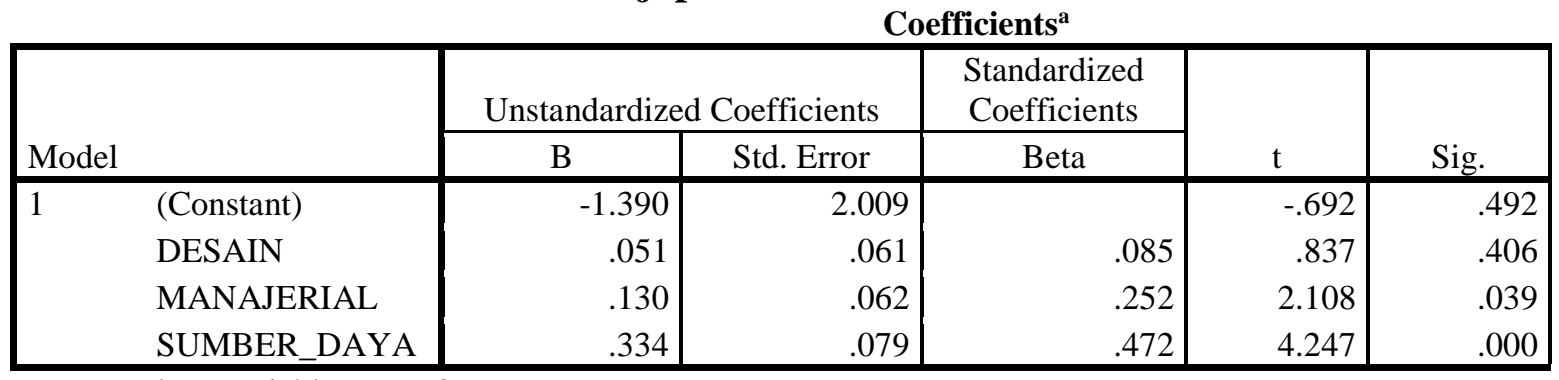

a. Dependent Variable: REWORK

Sumber : Hasil Pengolahan Data Melalui Program SPSS 22.0 (2017)

Berdasarkan tabel 4.5 dapat disimpulkan bahwa: 


\section{Desain}

Desain yang berupa kesalahan desain, perubahan desain, detail desain, kurangnya constructability dan buruknya dokumentasi berpengaruh secara positif dan tidak signifikan terhadap terhadap rework pada perusahaan konstruksi di kota Medan. Berikut ini adalah hasil pengujian parsial untuk desain:

thitung $=0,837>$ ttabel $=0,678$, maka tolak H0 (terima H1) Sig.hitung $=0.406>$ $(\alpha)=0.05$

\section{Manajerial}

Manajerial yang terdiri dari alur informasi yang kurang baik, kurangnya pengawasan yang dilakukan di lapangan, jadwal kerja tidak teratur, dan teamwork yang tidak solid berpengaruh secara positif dan signifikan terhadap rework pada perusahaan konstruksi di kota Medan. Berikut ini adalah hasil pengujian parsial untuk Manajerial:

$\mathrm{t}$ hitung $=2.108>\mathrm{t}$ tabel $=0,678$, maka terima $\mathrm{H}_{1}\left(\right.$ tolak $\left.\mathrm{H}_{0}\right)$ Sig.hitung $=0.039<$ $(\alpha)=0.05$.

\section{Sumber Daya}

Sumber Daya yang berupa pertimbangan yang salah dilapangan, kurangnya pengalaman kerja, bekerja tidak sesuai prosedur dan kurangnya pengetahuan pekerja berpengaruh secara positif dan signifikan terhadap rework pada perusahaan konstruksi di kota Medan. Berikut ini adalah hasil pengujian parsial untuk sumber daya:

thitung $=4,247>$ tabel $=0,678$, maka terima H1 ( tolak H0 ) Sig.hitung $=0.000$ $<(\alpha)=0.05$

\section{Analisis Beda ( One Way Anova )}

1. Desain

Tabel 4.6

Hasil uji anova desain( $F$ )

ANOVA

PERUSAHAAN

\begin{tabular}{|l|r|r|r|r|r|}
\hline & Sum of Squares & Df & Mean Square & F & Sig. \\
\hline Between Groups & 7.894 & 9 & .877 & 1.516 & .164 \\
Within Groups & 32.971 & 57 & .578 & & \\
Total & 40.866 & 66 & & & \\
\hline
\end{tabular}

Sumber : Hasil Pengolahan Data Melalui Program SPSS 22.0 (2017)

Berdasarkan Tabel 4.6 diperoleh nilai probabilitas signifikansi sebesar 0,164 > 0,05 hal ini berarti tidak terdapat perbedaan desain di perusahaan kontraktor PT. Leprim Globalindo Utama, CV. Bintang Multi Graha dan PT. Citra Anugrah Teknika. Nilai $F_{\text {hitung }}$ sebesar 1,516 $<\mathrm{F}_{\text {tabel }} 2,05$ hal ini berarti $\mathrm{H}_{0}$ ditolak dan $\mathrm{Ha}$ diterima atau dengan kata lain tidak terdapat perbedaan desain yang digunakan dalam perusahaan kontraktor tersebut. 
2. Manajerial

Tabel 4.7

Hasil uji anova manajerial ( F )

ANOVA

PERUSAHAAN

\begin{tabular}{|l|r|r|r|r|r|}
\hline & Sum of Squares & Df & Mean Square & F & Sig. \\
\hline Between Groups & 6.865 & 11 & .624 & 1.010 & .450 \\
Within Groups & 34.001 & 55 & .618 & & \\
Total & 40.866 & 66 & & & \\
\hline
\end{tabular}

Sumber : Hasil Pengolahan Data Melalui Program SPSS 22.0 (2017)

Berdasarkan Tabel 4.7 diperoleh nilai probabilitas signifikansi sebesar $0,450>0,05$ hal ini berarti tidak terdapat perbedaan manajerial di perusahaan kontraktor PT. Leprim Globalindo Utama, PT. Citra Anugrah Teknika dan CV. Bintang Multi Graha. Nilai $F_{\text {hitung }}$ dari variabel manajerial sebesar 1,010 $<\mathrm{F}_{\text {tabel }} 1,97$ hal ini berarti tidak terdapat perbedaan manajerial disetiap perusahaan.

3. Sumber daya

Tabel 4.8

Hasil uji anova sumber daya ( $F$ )

ANOVA

PERUSAHAAN

\begin{tabular}{|l|r|r|r|r|r|}
\hline & Sum of Squares & Df & Mean Square & F & \multicolumn{1}{c|}{ Sig. } \\
\hline Between Groups & 2.386 & 7 & .341 & .523 & .814 \\
Within Groups & 38.479 & 59 & .652 & & \\
Total & 40.866 & 66 & & & \\
\hline
\end{tabular}

Sumber : Hasil Pengolahan Data Melalui Program SPSS 22.0 (2017)

Berdasarkan Tabel 4.8 diperoleh nilai probabilitas signifikansi sebesar $0,814>0,05$ hal ini berarti tidak terdapat perbedaan sumber daya di perusahaan kontraktor PT. Leprim Globalindo Utama, PT. Citra Anugrah Teknika dan CV.

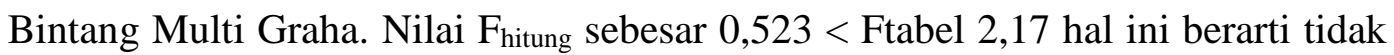
terdapat perbedaan sumber daya yang signifikan di perusahaan.

4. Rework

Tabel 4.9

Hasil uji anovva rework ( F )

ANOVA

PERUSAHAAN

\begin{tabular}{|l|r|r|r|r|r|}
\hline & Sum of Squares & Df & Mean Square & F & Sig. \\
\hline Between Groups & 4.502 & 6 & .750 & 1.238 & .300 \\
Within Groups & 36.363 & 60 & .606 & & \\
Total & 40.866 & 66 & & & \\
\hline
\end{tabular}

Sumber : Hasil Pengolahan Data Melalui Program SPSS 22.0 (2017)

Berdasarkan Tabel 4.9 diperoleh nilai probabilitas signifikansi sebesar $0,300>0,05$ hal ini berarti tidak terdapat perbedaan rework di perusahaan kontraktor PT. Leprim Globalindo Utama, PT. Citra Anugrah Teknika dan CV. Bintang Multi Graha. Nilai Fhitung sebesar 1,238 < Ftabel 2,25 hal ini berarti tidak terdapat perbedaan rework yang terjadi di perusahaan atau dengan kata lain rework 
yang terjadi di perusahaan PT. Leprim Globalindo Utama, PT. Citra Anugrah Teknika dan CV. Bintang Multi Graha memiliki kemiripan.

\section{Pembahasan}

Faktor desain berpengaruh positif dan tidak signifikan terhadap rework yang terjadi pada pekerjaan konstruksi di Kota Medan

Berdasarkan penelitian menunjukkan bahwa faktor desain berupa kesalahan desain, perubahan desain, detail desain yang tidak jelas, kurangnya constructability dan buruknya dokumentasi berpengaruh positif dan tidak signifikan terhadap rework yang terjadi pada pekerjaan konstruksi di Kota Medan. Hal ini dikarenakan data yang diperoleh dari responden menyatakan desain yang digunakan bukan desain yang terbaik, desainnya sering mengalami perubahan, dan detail yang digunakan tidak jelas sehingga dapat menimbulkan rework.

Faktor manajerial berpengaruh positif dan signifikan terhadap rework yang terjadi pada pekerjaan konstruksi di kota Medan.

Hasil penelitian menunjukkan secara parsial manajerial yang terdiri dari alur informasi yang kurang baik, kurangnya pengawasan yang dilakukan di lapangan, jadwal kerja tidak teratur, dan teamwork yang tidak solid berpengaruh signifikan dan positif terhadap rework yang terjadi pada pekerjaan konstruksi di kota Medan. Berdasarkan pernyataan responden buruknya alur informasi, kurangnya pengawasan yang dilakukan di lapangan, jadwal kerja tidak teratur, dan teamwork yang tidak solid yang menyebabkan terjadinya rework. Faktor manajerial berkaitan dengan seluruh unsur-unsur pengelola proyek konstruksi, baik itu pengguna jasa (pemilik proyek) dan penyedia jasa (kontraktor dan konsultan).

\section{Sumber daya berpengaruh positif dan signifikan terhadap rework yang terjadi} pada pekerjaan konstruksi di kota Medan

Hasil penelitian menunjukkan secara parsial sumber daya berpengaruh positif dan signifikan terhadap rework yang terjadi pada pekerjaan konstruksi di Kota Medan. Pernyataan dari responden yaitu pertimbangan yang dilakukan dilapangan tidak tepat, sumber daya yang digunakan tidak berpengalaman, pekerjaan tidak berjalan sesuai dengan prosedur yang ada adalah faktor terbesar dalam menyebabkan terjadinya rework. Faktor ini berkaitan dengan sumber daya manusia (pekerja/tukang) dan barang (peralatan kerja proyek). Faktor sumber daya biasanya muncul pada fase konstruksi yang akan mengakibatkan adanya kesalahan pengerjaan di lapangan karena kurangnya skill pekerja dan minimnya peralatan yang digunakan, sehingga pihak kontraktorlah yang lebih banyak terkait dengan faktor ini.

Tidak terdapat perbedaan faktor penyebab rework pada pekerjaan konstruksi di kota Medan. 
Berdasarkan hasil test anova menunjukkan bahwa tidak terdapat perbedaan faktor penyebab rework pada PT. Leprim Globalindo Utama, CV. Bintang Multi Graha dan PT. Citra Anugrah Teknika.

\section{KESIMPULAN DAN SARAN \\ Kesimpulan}

Sesuai hasil analisis data yang dilakukan dapat diperoleh beberapa kesimpulan antara lain :

1. Secara simultan faktor desain, manajerial dan sumber daya berpengaruh positif dan signifikan terhadap rework yang terjadi pada pekerjaan konstruksi di kota Medan.

2. Secara parsial faktor desain berpengaruh positif dan tidak signifikan terhadap rework yang terjadi pada pekerjaan konstruksi di kota Medan

3. Secara parsial faktor manajerial berpengaruh positif dan signifikan terhadap rework yang terjadi pada pekerjaan konstruksi di kota Medan.

4. Secara parsial faktor sumber daya berpengaruh positif dan signifikan terhadap rework yang terjadi pada pekerjaan konstruksi di kota Medan.

5. Berdasarkan hasil pengujian koefisien determinasi $\left(R^{2}\right)$ diperoleh nilai $R$ sebesar 0,675 yang berarti hubungan (relation) antara desain, manjerial dan sumber daya sebesar $67,5 \%$, artinya hubungannya erat. Nilai $R$ Square sebesa r0,456 yang berarti 45,6\% dapat dijelaskan faktor desain, manajerial dan sumber daya sebesar sedangkan sisanya sebesar $54,4 \%$ dijelaskan oleh faktorfaktor lain yang tidak dijelaskan dalam penelitian ini.

6. Tidak terdapat perbedaan faktor desain, manajerial dan sumber daya yang menyebabkan rework di perusahaan konstruksi kota Medan.

\section{Saran}

1. Pada faktor desain perusahaan diharapkan memperhatikan desain yang digunakan dan mengurangi perubahan desain, agar tidak terjadi kesalahan di lapangan karena desain merupakan panduan untuk pelaksanaan pekerjaan di lapangan.

2. Perusahaan diharapkan memperhatikan alur informasi, melakukan pengawasan yang rutin, jadwal kerja yang padat dan mempunyai teamwork yang solid sehingga dapat mengurangi terjadinya rework.

3. Faktor sumber daya merupakan variabel yang dominan mempengaruhi rework. Oleh karena itu perusahaan harus memperhatikan pertimbangan di lapangan, melakukan sistem rekrutmen yang sesuai agar mendapatkan karyawan yang memahami pekerjaannya dengan baik, memperhatikan pekerjaan berjalan sesuai prosedur. Perusahaan juga harus mengatur jadwal kerja karyawan agar mengurangi jadwal lembur, pekerja yang kurang memahami pekerjaannya karena hal tersebut menyebabkan terjadinya rework.

4. Peneliti selanjutnya sebaiknya memperluas objek penelitiannya, misalnya mengambil jumlah sampel yang lebih banyak atau mengambil jangkauan seluruh Indonesia. 


\section{DAFTAR PUSTAKA}

Abdul Rahman, H. The Cost of Non conformance during a Highway Project: A Case Study, Construction Management and Economics, 1995. Pp.23-32.

Andi, Samuel W dan Yanto H. 2005, Faktor-faktor Penyebab Rework Pada Pekerjaan Konstruksi, Jurnal Teknik Sipil Universitas Kristen Petra, Surabaya.

Assauri, S, Manajemen Produksi dan Operasi Edisi Revisi 2008”, Lembaga Penerbit FE-UI, Jakarta, 2008.

Burati, J.L, Farringgton J.J, and Ledbetter, W.B, Causes of Quality Deviations in Design and Construction, Journal of Construction Engineering and Management, 1992, pp.34-39.

Chundawan, E dan Alifen, R, S. 2014. Model Sumber dan Penyebab Rework Pada Tahapan Proyek Konstruksi.

[CII] Construction Industry Institute, Cause and Effect of Field Rework Research Team 2000. 153.

[COAA] Construction Owner Association of Alberta, 2002.

Fayek, et al 2004. Developing a Standard Methodology for Measuring and Classifying Construction Field Rework. Canadian Journal of Civil Engineering, Proquest Science Journal pg 1077.

Ghozali, Imam, 2006. Aplikasi Analisa Multivariat dengan Program SPSS, Cetakan Keempat, Badan Penerbit Universitas Diponegoro, Semarang.

Ghozali, Imam, 2009. Aplikasi Analisa Multivariate dengan Program SPSS, Cetakan Keempat, Badan Penerbit Universitas Diponegoro, Semarang.

Ghozali, Imam, 2011. Aplikasi Analisa Multivariat dengan Program SPSS, Edisi Kelima, Badan Penerbit Universitas Diponegoro, Semarang.

Ghozali, Imam, 2013. Aplikasi Analisa Multivariat dengan Program SPSS, Edisi Ketujuh, Badan Penerbit Universitas Diponegoro, Semarang.

Hansen, Don R, Mowen Maryanne M 2013 Cornerstones of Cost Management. Cengange Learning

Herjanto, E. 2007. Manajemen Operasi. Jakarta. Grasindo.

Hasugian Ronald. 2010. Analisis faktor-faktor penyebab rework pada pelaksanaan proyek konstruksi. Universitas Atma Jaya Yogyakarta.

Khan M. Y dan Jain P. K. 2006. Basic Financial Management, Edisi 2, Penerbit Tata McGraw-Hill Education Pvt. Ltd. New Delhi

Kuncoro, Mudrajat, 2009.Metode Riset untuk Ekonomi dan Bisnis, Penerbit Erlangga, Jakarta.

Kotler, P. dan Keller, K, L., 2007.Manajemen Pemasaran, Edisi 12, Jilid 1, PT. Indeks, Jakarta.

Love, P.E.D, Wyatt, A.D and Mohamed, S (2002), Understanding Rework in Construction, Proceeding International Conference on Construction Process Reengineering (Queesland) pp 269-278. 
Prawirosentono, S, 2007, Filosofi Baru Tentang Mutu Terpadu. Edisi 2. Jakarta: Bumi Aksara.

Santoso, R, Tingkat Kepentingan dan Alokasi Resiko pada Proyek Konstruksi, tesis, Universitas Kristen Petra, Indonesia, 2006

Sartika Yuni. 2013. Faktor-faktor penyebab pekerjaan ulang (rework) pada proyek gedung di Kabupaten Rokan Hulu berdasarkan persepsi kontraktor. Jurnal Teknik Sipil Universitas Pasir Pengaraian, Riau.

Situmorang, Syafrizal Helmi, dan Lutfi, Muchlis. 2011. Analisa Data :Untuk Riset Manajemen dan Bisnis. Edisi Kedua, USU Press, Medan.

Situmorang, Syafrizal Helmi, dan Lutfi, Muchlis. 2014. Analisa Data :Untuk Riset Manajemen dan Bisnis. Edisi Ketiga, USU Press, Medan.

Sugiyono, 2008. Metode Penelitian Bisnis, CV. Alfabeta, Bandung.

Sugiyono, (2012). Memahami Penelitian Kualitatif. Alfabeta. Bandung

Tabrani, Hidayat, A. Ariyanto, A. 2006. Faktor Penyebab Pekerjaan Ulang (Rework) Yang Berkaitan Dengan Manajerial Pada Proyek konstruksi Jalan di Kabupaten Rokan Hulu. Jurnal Teknik Sipil Universitas Pasir Pengaraian, Riau. 